NORDISK MUSEOLOGI $1996 \cdot 2$, S. $11-19$

\title{
ECOMUSEUMS BECOME MORE REALISTIC
}

\author{
Kenneth Hudson
}

You are all familiar with the philosophical notion that nothing exists until and unless there is a word to describe and define it. Let us suppose, for instance, that my language and yours had no word for 'weather'. We would all have experienced sunshine, rain, frost, snow and wind, and we would know that these conditions came and went, but we should only be able to think of them as separate phenomena, without any general concept, expressed by the term 'weather', to bind them together as natural happenings beyond human control. The presence of the word 'weather' in the language changes our attitude to its individual components. They are all 'weather', so that we are able to have weather forecasts and weather reports, instead of merely rain forecasts and snow reports.

The same consideration applies to so many features of our lives. Our thinking is sharpened and focused by the arrival of a new word. Until the 1960s, there were only derelict factories, old railway stations and disused canals and few people took the slightest interest in them. And then the term 'industrial archaeology' was invented. Almost overnight this mass of crumbling buildings and rusting machines became important historical material, deserving preservation and careful study. A new academic discipline came into being. A label had made people notice and value what had previously been regarded as eyesores and junk.

The coining of the word 'eco-museum' in the 1960s had a very similar effect, and since it was first used in France, in the form of 'écomusée', it is generally assumed that the ecomuseum was a French invention. In a sense this is true - the word compelled and encouraged people to look at a certain kind of historical evidence in a different way. But the achievement of Hugues de Varine and Georges Henri Rivière was not to create what existed in and around Le Creusot, but to act as its impresarios. Once they had, so to speak, thrown their warm and loving arms around this scatter of old industrial buildings and brought it to life by baptising it as 'an eco-museum', it became permanently upgraded and worthy of scholarly and official attention. It acquired a personality and an allure. 


\section{$B A G A M O Y O$}

At this point I think I could helpfully indulge in a little autobiography. In 1975, through the generosity of UNESCO, which had quite a lot of money to spare in those golden days, I found myself in Tanzania, where I was taken to a small town called Bagamoyo, on the coast, by a very friendly and helpful member of the British Council's staff in Dar-es-Salaam. The journey took two hours and the road at that time was exceedingly bad, although it has since been improved in the interests of tourism, that great destroyer of developing countries.

Bagamoyo has a remarkable history. A century ago it was both commercially and politically far more important than the present capital of Tanzania, Dar-es-Salaam, which at that time was no more than a fishing village. Its development began in 1832, when Sultan Said, the Imam of Oman, transferred his capital there from Muscat, in Zanzibar. Because of its proximity to Zanzibar and the fact that dhows could cross the channel at all times of the year, it became a great commercial centre. A trade route was created from Bagamoyo to lake Tanganyika. The starting point of the track, which linked the coast road with the heart of Africa, is still clearly indicated by a blockhouse, with loopholes and fire-steps, which was built in 1889 by the Germans.

This is where many journeys of exploration started. A plaque set up near the beach and not far from the blockhouse, commemorates the first of these expeditions, undertaken by the British explorers, Burton and Speke, who set off from here on 27 June 1857.
Bagamoyo was not only a starting point. For many thousands of slaves it was the end of a terrible march in chains right across East Africa. This was probably responsible for the change in the town's name from Bwagemoyo, which means 'Throw off your melancholy', to Bagamoyo, 'Crush your heart'. There was never a slave market in Bagamoyo, but there was a gathering point, a caravanserai, where a great many slaves must indeed have laid down their hearts before being shipped away by dhow to Zanzibar. Others were fortunate enough to be set free on payment of a ransom, paid for the most part by the Roman Catholic Mission founded here in 1868 by the Holy Ghost Fathers. I visited the Mission, which came into existence to liberate slaves and to educate them once they were free. It looked much as it must have done in its early days. One of the buildings contained a little museum, setting out the history of Bagamoyo. Its collection, which made a deep impression on me, included a beautifully written register of slaves freed by the Mission, with the name of each slave, where he came from, and the date of his baptism.

It was the same Mission that took care of Dr Livingstone's body when it was brought back here in February 1874, by a party of exhausted men who had carried it for hundreds of miles. The church in which it had rested overnight had gone, but its tower remained, as did the Grotto of the Blessed Virgin, built by former slaves as an expression of gratitude to the missionaries who had saved them. Another witness to the Mission's care for the sick and the poor was an old hospital, built in 1897 with funds provided by a 
rich Indian and run by nuns until 1912, when it was taken over by the Government.

During the Arab revolt against German rule in East Africa, the German military commander made Bagamoyo his headquarters. The German cemetery and four large bronze plaques commemorate the German officers and soldiers who were killed during the fighting. The large fortlike building, now used for the civil administration of the area, was constructed by the Germans to act as their base. The old German Customs House was still standing and opposite it I saw the stone and iron foundations of its warehouse. It was raised above ground and had a moat around it which could be filled with water in an emergency, in order to prevent the local population from entering it and looting the store. In the town square there was a double-faced German-made clock, bearing the date, 1900, and the maker's name and address. This ancient town, ruled and developed successively by Arabs, Germans and English, before it became part of an independent Tanzania in 1961, remains a centre of traditional Swahili culture. I saw evidence of this in the beautifully carved street doors. The carvings contain a great deal of symbolism - the lotus, as a symbol of generation; the date-tray, denoting plenty; the fish, fertility; the chain, security; and frankincense, wealth.

At the time when I visited it 20 years ago, Bagamoyo was uncorrupted by tourism. It was neither particularly respected, nor particularly cherished, but it clearly had the potential to become one of Africa's most interesting and significant ecomuseums. Nowhere shows better the different layers of foreign power and cul- ture which have been laid down in Africa and the extent to which they have been absorbed or ignored. The whole town was a wonderful museum-in-the-making, requiring no heavy expenditure to interpret it as a major historical resource. It was Bagamoyo, which I visited in 1975, which really converted me into an enthusiast for the area-as-museum concept, or ecomuseum as this came to be known when a professionally sanctified label was thought to be required. What Bagamoyo needed was an impresario and it was its misfortune and an historical accident that the impresarios at that time happened to be devoting their attention and their prestige to sites in France, not in Tanzania. So the birth of the ecomuseum was registered in France, which was perfectly logical, but unjust. Life, of course, is not just and in the museum race, as in all others, there have to be both winners and losers.

But suppose someone in Tanzania had said, 'Looked at as a museum, Bagamoyo is as worth supporting as the National Museum in Dar-es-Salaam'. For whom would this new museum, or rather, this new concept of a museum have been created? There are two possibilities. The first is that it would have been aimed mainly at the people who lived in the town and the surrounding area. In this case the older buildings in Bagamoyo, including those mentioned above, could have formed part of a history-walk, with signposts and interpretative panels to draw attention to them and to illustrate what had happened locally during roughly the past 150 years. A regular programme of talks and activities could have been arranged and the archaeology closely linked to history teaching in schools. Such a policy could have 
14 made clear that the ecomuseum concept had been brought into being mainly in order to help to bring the past alive to the people whose homes were in Bagamoyo today.

The second possibility was that the transformation of Bagamoyo into an ecomuseum would have been planned for the benefit of tourists, as part of a wider scheme to attract foreign visitors to Tanzania. This would have required a considerably bigger investment, the preparation of the kind of publicity and information that international tourists demand and the installation of facilities that go hand in hand with the development of tourism. All this would have changed the atmosphere and appearance of Bagamoyo, a process which always and inevitably takes place when an historic site is made ready to receive and please thousands of visitors a year, instead of a small party from time to time. Those who encourage tourists for the sake of the money they inject into the local economy have to accept the nonfinancial consequences, which, as we now know, can be very disagreeable. But I have no doubt that people skilled in the art of tourism could have made a great success of Bagamoyo. The two basic ingredients, slavery and exploration, presented a heaven-sent opportunity to make a lot of money.

This dilemma, whether to think of local people first and stay small, or to go unhesitatingly for numbers and to work out the techniques necessary to obtain them, has been at the heart of ecomuseum politics for more than a quarter of a century. There is, of course, a third possibility, which consists of having no policy at all and doing nothing. This, broadly spea- king, is what has happened to Bagamoyo. The archaeology is still there, but it does not add up to anything. It continues to be an assembly of bits and pieces, without cohesion, interpretation or promotion. One could say the same about most of the world's potential ecomuseums. They remain embryonic.

In an ideal world - and there is no need to remind you that the world in which we live is far from ideal - the history of every area and every street in every country would be continuously explained to the people who lived there. At the very least, everyone should be familiar with the story of the house and street in which they live and the building and enterprise where they work. Not to know these basic details is to pass one's days on the surface, with no historical depth to one's existence. I have often thought, too, that it should be compulsory for every shop, café and restaurant to put up a short wall-history of the present business and of its predecessors on the same premises. People should be persuaded and helped to get into the habit of thinking historically.

\section{A PROJECT CALLED NORFOLK HERITAGE}

One of the most interesting attempts to achieve this was made during the late 1970s in the English county of Norfolk, which has Norwich as its capital city. The project, called Norfolk Heritage, eventually formed part of the Norfolk Museums Service, after a pioneering period financed by the Carnegie Trust. The aim was nothing less than to interpret the total heritage of the county of Norfolk to the public, to encourage the understanding of 
the county as a whole and, I quote the organisers, 'to treat the total heritage of the region as a collection, the region itself being a kind of museum to be drawn upon to illustrate the region's story and the story of the life and work of the people'. Explanatory texts, plans and diagrams were provided on hundreds of information boards set up at strategic sites throughout the county and the local material was correlated with more ambitious displays in museums. The range of information covered geology, natural history, building materials, social and economic history and farming methods and the interrelationship between all these branches of knowledge were emphasised, in order to provide a total picture of the Norfolk landscape and environment.

The Norfolk Museums Service announced that it was 'trying to bring the landscape alive' for the benefit of those who lived and worked in it all the time. The heritage of any region, it believed, was of greatest importance to the people who were always surrounded by it. Visitors were a bonus.

\section{MARQUËZE AND CAMARGUE}

'Visitcrs are a bonus' could be taken as the motto, the credo, of what one might call the ecomuseums in their golden age, when economic pressures were not as severe as they were to become during the 1980s and 1990s. The first French experiments with ecomuseums were carried out during the 1960 s, in very rural areas. The aim was to present the traditional local culture within the natural environment where it had flourished and developed. The pattern of organisation varied according to the district. The ecomuseum of Marquèze was set up within the Regional Natural Park of the Landes de Gascogne. It was actually a hybrid development of a much older type of institution, the open-air museum. Characteristic timber-framed farmsteads from the central part of the Landes were brought to the site, together with the domestic, handicraft and agricultural equipment used by the peasants. The appropriate livestock was added to the mixture. This, visitors were told, was how people lived and worked in this area until very recently. They were the ancestors of the families now living there.

The exhibits at Marquèze were spread over a large site, so as to create the impression of having always been there. There was therefore an element of fraud in the scheme. Added to these imported items was an 'environmental museum', the purpose of which was 'to bring out the changes in the environment wrought by man and the inter-action between animal, vegetable and mineral elements within the ecological context'. Here the main intention was to create an interpreted collection which would be interesting to local people. Visitors were regarded as an accident, possibly God-given, possibly not.

A slightly different emphasis was to be found at the Camargue Museum in the Camargue Regional Wildlife Park, near Arles. The Camargue is thinly populated, with only about 8,500 people living there all the year round. The purpose of the Museum, run by a Foundation, was to bridge the cultural gap between the residents and the tourists. The necessary information was to be provided, so far as possible, by the inhabitants of the Camargue themselves, resulting in an exchange 
KENNETH HUDSON

16 of ideas between them 'and their guests'. The use of the phrase 'and their guests' was significant. The tourists were to be regarded as having been invited by the residents to come to the Camargue to meet them. For this reason, the people whose home was in the region were felt to have the duty of taking an active part in providing material and ideas for the Museum. By making a direct contribution in this way and by being involved in the planning from the beginning, they were being given the opportunity to gain a much deeper understanding of their own traditions and environment. They would be participants in the enterprise, not observers.

This, at least, was the theory. To give someone the opportunity of participating does not necessarily mean that he will participate and in the Camargue, as at Marquèze, there were inevitably some people who did a great deal and others who did little or nothing. What one can fairly say, however, is that the atmosphere was one of co-operation.

The Camargue Museum relied on what its organisers referred to as 'the doubleinput system', that is, a fruitful collaboration between professionals and amateurs. The professionals provided the guidelines as to what had to be done, the amateurs collected the material and the information and the professionals shaped it up, disciplined it and presented it in an attractive and meaningful way.

The French eventually established more than 30 ecomuseums. All of them in their different ways, have broken new ground and taken together represent one of the most important museological developments of the years since the Second World
War. Their common features have been a determination to involve local volunteers in the planning and operation and to consider the resources of an area as a whole, making no clear distinction between manmade features and the natural environment, or between past, present and future. They have been based on the conviction that by understanding the past, one is likely to make a better job of handling the present and preparing for the future.

\section{LE CREUSOT}

The French ecomuseum which has had the most influence abroad and which, at least in its vintage years, has exploited the 'double-input system' in the most thoroughgoing manner is almost certainly the Museum of Man and Industry at Le Creusot. It was a classic site. From the late 18 th century until the mid-20th Le Creusot had been one of the most important industrial regions in France. Its prosperity had been built around the production of armaments and railway locomotives, with the Schneider family, which came originally from eastern France, as the major entrepreneurs. After the Second World War, the Schneiders fell into disgrace, as a result of collaboration with the Germans. Their manufacturing empire collapsed, leaving Le Creusot destitute.

The establishment of new forms of employment was, of course, the first priority, both for the municipality and for the central government, but raising the morale of the district was also important and a group of influential people, among them the then Secretary-General of ICOM, Hugues de Varine, and his predecessor, Georges Henri Rivière, had the imagina- 
tive idea that a special kind of ecomuseum, a Museum of Man and Industry, could make a strong contribution to this. What they had in mind was a kind of museum therapy, in which local people would not only help to create the museum, but would themselves be living exhibits in it.

This Mark Two ecomuseum was to be concerned with an area of about $500 \mathrm{~km}^{2}$, half industrial and half rural, divided into 25 communes, with a total of 150,000 inhabitants. It contained two urban communities, Le Creusot, whose income had been based on manufacturing, and Montceau-les-Mines, a coalmining town. The Schneiders had lived close to the Works at Le Creusot, in a splendid 18th-century château with a park and, in its forecourt, the impressive glass-cones of the Manufacture Royale de Cristaux, which had been established in 1783, not long before the Revolution.

Work on the development of the Museum of Man and Industry began in 1971 and, in so far as one can open such a museum, it was opened in 1974, after its philosophy had been set out by Hugues de Varine in these words. 'Any movable or immovable object within the community's perimeter,' he wrote in an article for the UNESCO journal, Museum, 'is psychologically part of the museum'. This introduces the idea of a kind of "cultural property right», which has nothing to do with legal ownership. Accordingly, it is not the function of the museum as such to make acquisitions, since everything existing within its geographical area is already at its disposal.

'But the 'fragmented museum' had to be given a core, an interpretation point, and at
Le Creusot this was to be in the château, which had been the centre of the industrial spider's web woven by the Schneiders. The old web had been brushed away and the people were making a new one. The displays in the château were to illustrate the general history and character of the area, the daily life of its people over the centuries and its artistic and industrial products. The château was also to serve as a base for research into industrial civilization, so that the Museum of Man and Industry could be set within a wider context.

Permanent, professional staff were essential, but their number should be kept to a minimum. 'They have to infuse life into the institution and act as a catalyst. Professional museum staff are also needed for the technical side, in order to carry out research, keep catalogues up-to-date, organise events and complex projects, ensure continuity, co-ordinate the otherwise haphazard activities of the various sections of the community, and represent the interests of the museum in dealing with the authorities. The members of this permanent team, who must live in symbiosis with the population, must naturally be as discreet, modest and approachable as possible.'

There are strong echoes of Rousseau and Voltaire in all this, of the theoreticians of the French Revolution, which is another way of saying that both Hugues de Varine and the Museum of Man and Industry are very French. The French demand a philosophy as a basis for action. They like to see the ends neatly tied in. I have no doubt at all that the ecomuseum idea, with the prestige of Georges Henri Rivière and Hugues de Varine behind it, have had 
18 a profound influence on museum thinking throughout the world. But I have been struck by the fairly obvious fact that extremely few 'fragmented museums' outside France have shown any great desire to call themselves ecomuseums, although there are open-air museums in plenty and their number is growing all the time. Museum people from all over the world have beaten a path to Le Creusot, which has become a Lourdes or Compostella of the museum world, but they have felt inclined to imitate it only up to a certain point. This may be because other countries have not had museum gospel preachers of the calibre of Rivière and de Varine, because French institutions and ideas do not, in general, export satisfactorily, or simply because the name 'écomusée', or its literal translations, failed to strike a sympathetic chord elsewhere.

The raw material of ecomuseums is, of course, to be found everywhere. As I have often said and written, Europe is nothing more or less than a giant network of potential ecomuseums. It has a cellular structure and every district is an historical cell, waiting to be identified, interpreted and publicised. One very real problem, especially in Britain and the English-speaking world, is that 'eco' suggests 'echo', reflected or reverberated sound, not an abbreviation of 'ecological', so that an 'eco-museum' becomes 'an echo of a museum, an unreal museum, a shadow of a museum', a concept which is not likely to attract supporters.

\section{IRONBRIDGE GORGE}

It is interesting to compare the Museum of Man and industry at Le Creusot with the museum complex at Ironbridge Gorge in central England. Both were places of pilgrimage during the 1970 s and 1980 s but not, alas, today and there are certain similarities between them - the scattered sites, the central interpretative museum, the cluster of 'antennae' or small subsidiary museums, the integrated management, the well-organised research base - but the differences are and always have been equally significant. Ironbridge, belonging to a Trust, has always needed to raise the greater part of its funds by its own efforts and consequently, in its development, it was designed mainly to attract and please visitors from outside the area. Le Creusot was brought into being to enrich the lives of the local inhabitants, although this philosophy has worn a little thin over the years. Restoration and conversion work at Ironbridge has cost a great deal of money, but at Le Creusot comparatively little. Income derived directly from visitors has been exceedingly important at Ironbridge, but at Le Creusot it has not had a high priority.

It is self-evident that a museum's financial base has a great deal to do with the way in which it presents its cultural assets to the public. If admission charges, shop sales and restaurant profits form a major part of the museum's income, greater attention will inevitably have to be paid to showmanship and publicity. During the past five years, conditions have become steadily more difficult for nearly all museums in all countries. Municipal and state budgets have been cut, unemployment has increased and people have less to spend on going to museums. The Le Creusot philosophy, so confidently expressed by Hugues de Varine 20 years ago, 
feels like an unattainable luxury today.

The Le Creusot revolution, like the French Revolution and every other revolution eventually has to come to terms with harsh reality and to compromise to a greater or lesser extent if it wants to survive. The French ecomuseums have survived by abandoning their revolutionary principles and becoming respectable, which means, in essence, accepting the authority and canons of behaviour of the central authority, Les Musées de France. Ecomuseums and near-eco-museums elsewhere are surviving, often with great difficulty, by frankly admitting that they are in the market-place and by learning the art of getting their money from whatever sources they can, forgetting some of their 'principles' in the process.

\section{NOTE}

This paper was presented May 301996 at Riksutställningar, Stockholm, in honour of Ulla Keding Olofsson.

Kenneth Hudson är direktör forr det europeiska museiprisets sekretariat $i$ Bristol. Han presenterades utforligt i Nordisk Museologi 1996/1 i anslutning till sin artikel 'The wrong and the right road for museums'. Adr: EMYA, PO Box 913, Bristol BS99 5ST, England Fax +44-1179732437 